\title{
Genetics of Fibre Elongation in Diploid Cotton
}

\author{
G. Sunil Kumar, N.V. Mohan Kumar* and I.S. Katageri \\ Department of Genetics and Plant Breeding, University of Agricultural Sciences, \\ Dharwad- 580005, Karnataka, India \\ *Corresponding author
}

\begin{tabular}{|l|l}
\hline \multicolumn{1}{c|}{ A B S T R A C T } \\
\cline { 2 - 3 } \multicolumn{1}{c|}{$\begin{array}{l}\text { Keyword s } \\
\text { Fiber initiation, Fibre } \\
\text { elongation, Fuzzy. }\end{array}$} & $\begin{array}{l}\text { Genetics of fibre elongation in diploid cotton was studied during 2015-16 at } \\
\text { University of Agricultural Sciences Dharwad. Segregating population }\left(\mathrm{F}_{2}\right) \text { of the } \\
\text { cross between, Fuzzy linted (FL) x Fuzzy-lintless (Fl) of diploid cotton were } \\
\text { evaluated to study the genetics of fibre elongation. The segregation was in the } \\
\text { ratio 15(linted): 1(lintless) to indicating duplicate dominant gene action and } \\
\text { lintless trait is controlled by double recessive genes. Scanning electron microscopy } \\
\text { Article Info }\end{array}$ \\
$\begin{array}{l}\text { Accepted: } \\
\text { 07 September 2017 at fibre initiation stage i.e., two days post anthesis (2 DPA) to observe the } \\
\text { Available Online: } \\
\text { 10 November 2017 } \\
\text { of fibre cell initials in both FL and Fl line; however the fibre initials in Fuzzy- } \\
\text { lintless (Fl) line did not elongate to become lint, unlike FL, where part of initials } \\
\text { elongated into lint (fibre) cell. }\end{array}$ \\
\hline \hline
\end{tabular}

\section{Introduction}

Cotton is most important textile fibre crop of India and world. Cotton fibres are unicellular trichomes originating from the outer epidermal layer of the seed coat. About 20 to $25 \%$ of the seed epidermal cells differentiate into spinnable fibres (Arpat et al., 2004; Wilkins et al., 2005; Hee et al., 2001; Stewart, 1975). Fibre development includes four distinct, but overlapping stages namely initiation, elongation/primary cell wall (PCW) synthesis, secondary cell wall (SCW) synthesis and maturation. The lint fibers initiate growth between anthesis and 2 days post anthesis (DPA) and can elongate 2.5-3.5 $\mathrm{cm}$. Whereas, the fuzz fibers initiate growth between 5 and 10 DPA and are approximately $0.5 \mathrm{~cm}$ (Stewart, 1975). However, fast elongation of fibre cell occurs between 5 to 15 DPA. Secondary cell wall synthesis starts at about 20 DPA and continues up to 45 DPA. During this period large amount of cellulose (> $90 \%$ ) deposition takes place and the fibre cell wall becomes thick. In the final maturation stage (45-50 DPA) fibres undergo dehydration and produce mature cotton lint (Arpat et al., 2004; Wu et al., 2006). Cotton fibre initiation has been mostly studied in upland cotton, G. hirsutum, although some information exists on a few wild cottons (Applequist et al., 2001). Lint yield depends on number of bolls per unit area, number of seeds per boll, number of fibres per seed, number of fibres per unit area and average weight per fibre. Improvements in fibre 
number per seed and thereby fibres per unit area of seed might result in increased lint yield. Therefore, in the present study from the cross $(\mathrm{FL} \times \mathrm{Fl})$ an attempt was made to understand the variation for number of fibres per unit area in segregating $F_{2}$ population besides genetics of fibre elongation.

\section{Materials and Methods}

The genetics of fibre elongation in cotton was studied in $\mathrm{F}_{2}$ of population of cross between Fuzzy linted (FL) and Fuzzy-lintless (Fl) during kharif 20015-16 at Main Agriculture Research Station (D block), University of Agricultural Sciences, Dharwad. Fuzzy-linted (FL) and Fuzzy-lintless (Fl) lines (parents) and their $F_{1}$ and $F_{2}$ plants were used as genetic material in the study. About $309 \mathrm{~F}_{2}$ plants were observed for normal linted and lintless trait. Around 5 bolls per plant were observed at fully opened boll stage. The data was analysed applying chi-square test to work out genetics of fibre elongation. Ginning outturn was calculated in all $\mathrm{F}_{2}$ plants.

\section{Scanning Electron Microscopy}

At fibre initiation stage (2 DPA) scanning electron microscopy (SEM) was performed to observe the development of fibre initials on epidermal layer of ovules. Ovules excised from two days post anthesis flowers were collected in $3 \%$ glutaraldehyde and dipped in 1-2 \% osmium tetroxide for post-fixation. Samples were dehydrated in a graded acetone solutions and mounted on stub and allowed for metal coating with Gold using polaron sputter (E5100, Watford England) coater. The SEM images were captured by LEO $435 \mathrm{VP}$ (LEO Electron microscopy Ltd., Cambridge, UK) at $15 \mathrm{kV}$ EHT at Central Food Technological Research Institute (CFTRI), Mysore. The number of fibre initials was quantified in $100 \mu^{2}$ area using ImageJ software.

\section{Results and Discussion}

\section{Number of fibre initials in parents}

The SEM images of ovule (2 DPA) revealed that chalazal and middle parts of ovules were entirely covered with fibre initials whereas, extreme micropylar part of ovule is free from fibre initials (Fig. 1A and 1B). The absence of fibre initials at extreme micropylar end of ovules (2 DPA) and presence of fibres on outer epidermal layer of matured seeds at micropylar end indicates that, the fibre initiation in micropylar end takes a later stage. About 68 fibre initials were observed in Fuzzy-linted (FL) and 53 in Fuzzy lintless (Fl) (Table 2 and Fig. 1C, 1D). However, fibre initials in Fuzzy lintless did not elongate to become fibres (lint). As per the literature (Turley et al., 2007; Stewart, 1975; Joshi et al., 1967 and Lang, 1938) fibre initiation at the chalazal end of the ovule and progresses towards the micropylar end. The cells which show indication of elongation by 2 DPA are said to further elongating into either fuzz (0.5 $\mathrm{cm})$ and lint $(2.5$ to $3.5 \mathrm{~cm})$. Only 20 per cent of such initials cells showing elongation by 2 DPA are known to elongate into fibres (Arpat et al., 2004; Wilkins et al., 2005; Hee et al., 2001; Stewart, 1975). In figure 1 fibre initials were observed in both linted (FL) and lintless (Fl) cotton at 2 DPA but fibres were observed only in linted (FL) (Fig. 2).

\section{Genetics of fibre elongation}

The G. herbaceum (A genome) diploid cotton is normal fibred cotton which was crossed with $G$. anomolum (B genome), and the $\mathrm{F}_{1}$ was partially fertile, the partial fertile $\mathrm{F}_{1}$ was used as male and $G$. herbaceum was used as female to obtain $\mathrm{BC}_{1} \mathrm{~F}_{1}$ plants. $\mathrm{BC}_{1} \mathrm{~F}_{1}$ plants were fertile, they were further continued to derive recombinant inbred lines (Choudki et $a l$. , 2013). Two lines of $\mathrm{BC}_{1} \mathrm{~F}_{9}$, one being normal Fuzzy-linted (FL) and another Fuzzy- 
lintless $(\mathrm{Fl})$ were used to study the genetics of fibre elongation in present study.

Morphologically both fuzzy-linted (FL) and Fuzzy-lintless (Fl) lines were similar for traits like plant height, leaf size, leaf hairiness, stem pigmentation, stem hairiness, boll shape, boll colour, petal colour, pollen colour, anther colour and anther filament colour. So far no studies on genetics of fire elongation were conducted from such Fuzzy-linted (FL) and Fuzzy-lintless (Fl) diploid cotton. In present study based on observation on $309 \mathrm{~F}_{2}$ plants for normal fibred (linted), versus fibreless (lintless), the presence of two gene interaction was evident from Chi-square test to indicate double recessive nature of gene interaction is responsible for lintless trait (Table 1).

Fig.1 SEM micrograph of 2 DPA ovule
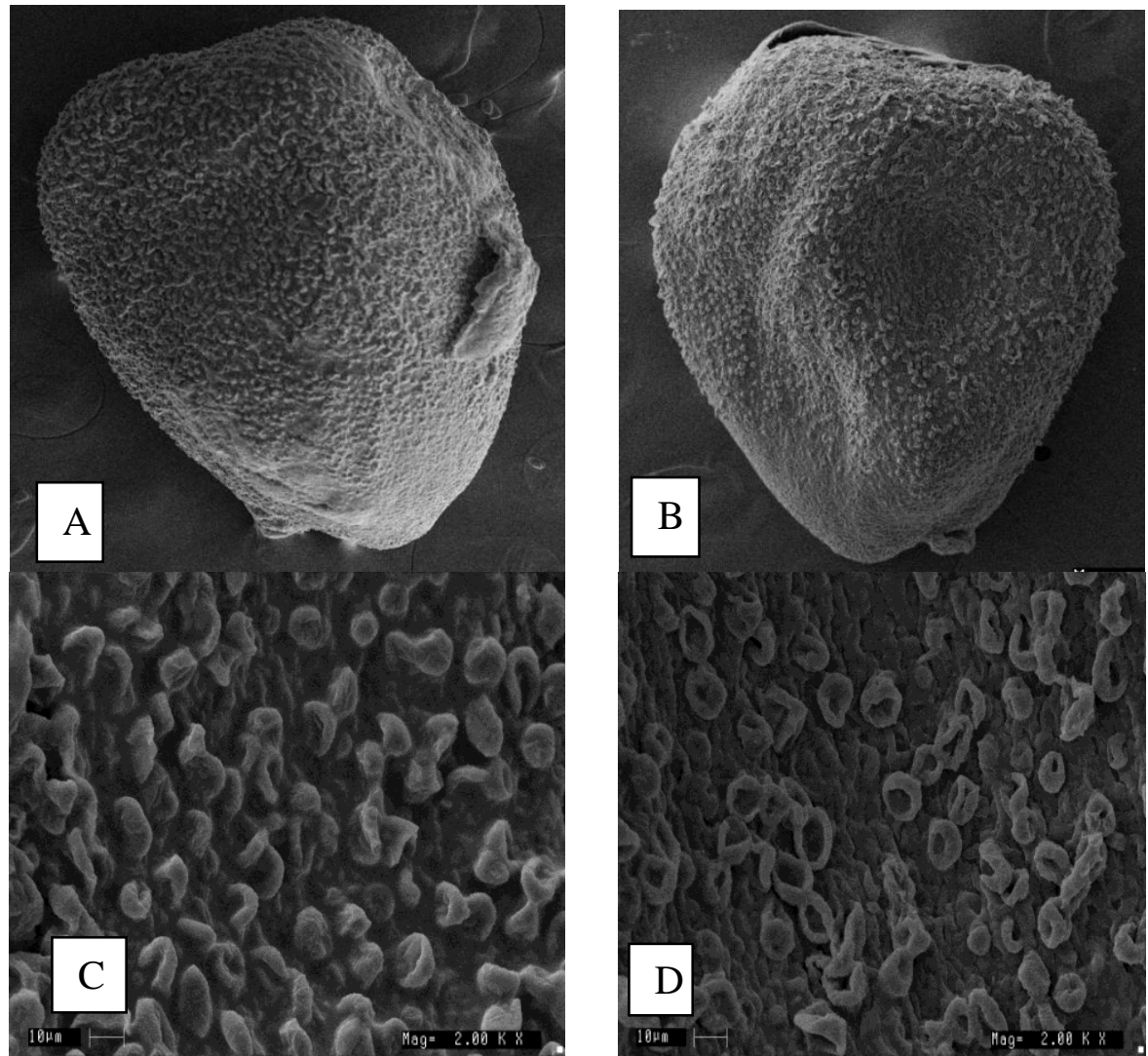

A: Fuzzy linted (FL), B: Fuzzy lintless (Fl), C: FL ovule surface $\left(100 \mu \mathrm{m}^{2}\right)$ and D: Fl ovule surface $\left(100 \mu \mathrm{m}^{2}\right)$.

Fig.2 A: Opened boll of FL, B: Opened boll of Fl
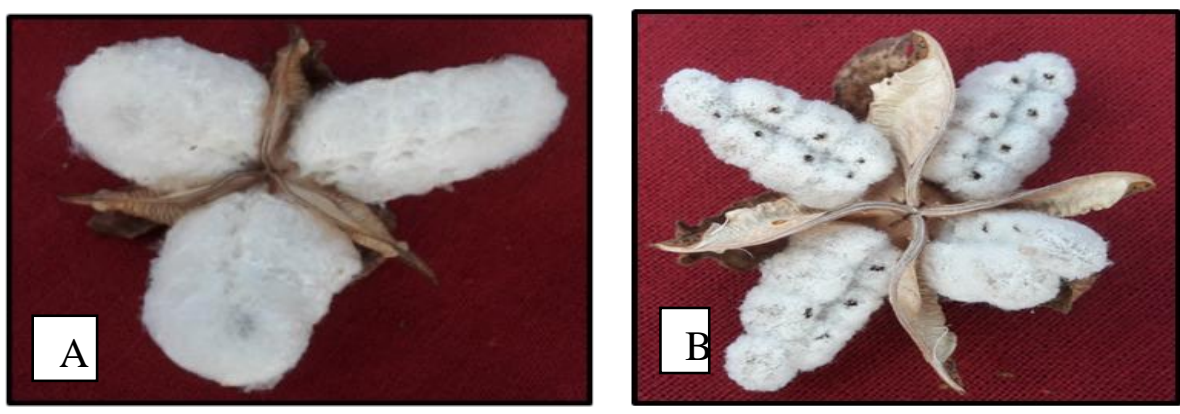
Table.1 Chi-square table

\begin{tabular}{|l|l|l|l|l|l|l|l|}
\hline Cross & \multicolumn{2}{|l|}{ Linted } & Lintless & $\begin{array}{l}\text { Total } \\
\text { number } \\
\text { of plants }\end{array}$ & $\begin{array}{l}\chi^{2} \\
\text { Value }\end{array}$ & $\begin{array}{l}\text { Table } \\
\chi^{2} \\
\text { Value }\end{array}$ \\
\cline { 2 - 8 } & Observed & Expected & Observed & Expected & 0.477 & 3.84 \\
\hline $\begin{array}{l}\text { Fuzzy-linted } \times \\
\text { Fuzzy-lintless }\end{array}$ & 287 & 290 & 22 & 19 & 309 & 0.4 & \\
\hline
\end{tabular}

Table. 2 Number of fibre initials per $100 \mu \mathrm{m}^{2}$ area of 2 DPA ovules

\begin{tabular}{|l|l|c|}
\hline Sl. No & Genotype & Fibre initials per $100 \mu \mathrm{m}^{2}$ \\
\hline 1 & Fuzzy-linted (FL) & 68 \\
\hline 2 & Fuzzy-lintless (Fl) & 53 \\
\hline
\end{tabular}

Table.3 Mean and range for ginning outturn in segregating population

\begin{tabular}{|c|c|c|c|}
\hline Character & Population $\left(\mathbf{F}_{\mathbf{2}}\right)$ & Mean & Range \\
\hline GOT $(\%)$ & Fuzzy-linted $(\mathrm{FL}) \times$ Fuzzy-lintless $(\mathrm{Fl})$ & 36.70 & $0.0-38.08$ \\
\hline
\end{tabular}

GOT: Ginning outturn

Variability for ginning out turn in diploid cotton

Ginning outturn, the proportion of lint in total kapas is mainly depending on number of fibres elongated from the surface of the epidermal layer, rather than fibre length. It is very clear from the difference in ginning outturn between different cultivated species. For example genotype belongs to $G$. barbadense are considered as extra-long staple cotton as their fibre length is more than $32 \mathrm{~mm}$, however the ginning out turn or lint yielding ability of these extra-long staple cotton is always between 32 to $34 \%$.

Whereas in case of $G$. hirsutum the fibre length varies from 24 to $30 \mathrm{~mm}$, and ginning out turn also varies between 35 to $40 \%$. The higher ginning out turn in $G$. hirsutum cotton may be due to the more number of fibres per unit area than the fibre length. Therefore the present study has been validation to find out genetic variability for number of fibre initials and elongating fibres in segregating population $\left(\mathrm{F}_{2}\right)$ obtained from the cross between Fuzzy-linted (FL) and Fuzzy-lintless (Fl) cotton.

In diploid cotton to measure number of fibres elongated, the main trait considered for recording observation was ginning outturn. There were only two classes in $F_{2}$, one was lintless and other was linted. Ginning outturn of all lintless $\mathrm{F}_{2}$ plant was however $0 \%$, whereas among the linted $\mathrm{F}_{2}$ plant ginning out turn varied from 29.31 to $38.08 \%$ (Table 3). So the observed variation for ginning outturn is due the increase in number of fibres per unit area. To increase ginning outturn in normal fibred cotton genotype is therefore possible by increasing number of elongating fibres. The genetic material evaluated under present study would be the valuable material for understanding molecular basis of fibre cell elongation in future.

\section{Abbreviations}

DPA: Days Post Anthesis, FL: Fuzzy linted, Fl: Fuzzy lintless, SEM: Scanning Electron Microscope 


\section{References}

Arpat, A. B., Waugh M, Sullivan J. P, Gonzales M, Frisch D, Main D, Wood T, Leslie, A, Wing R. A, Wilkins T. A., 2004, Functional genomics of cell elongation in developing cotton fibers. Plant Mol Biol., 54(6):911-929.

Choudki, V. M., Savita, S. G., Prashanth sangannavar, Vamadevaiah, H. M., Khadi, B. M., Patil, R. S and Katageri,I. S., 2013, Genetic improvement of fibre strength in diploid cotton $(G$. herbaceum L.) through interspecific hybridization using G. anomalum wild species. Crop Res. 45 (1):259-267.

Hee, K. M., and Barbara, A. T., 2001, Cotton Fiber Growth in Planta and in Vitro. Models for Plant Cell Elongation and Cell Wall Biogenesis. Plant
Physiol.127: 1361-1366

Joshi, P.C., Wadhwani, A.M and Johri, B.M., 1967. Morphological and embryological studies of Gossypium L. Proc. Natl. Inst. Sci. India, Part B, Biol. Sci. 33:3793.

Lang, A.G., 1938. The origin of lint and fuzz hairs of cotton. J. Agric. Res. 56:507521.

Stewart, J. D., 1975, Fiber initiation on the cotton ovule.Amer. J. Bot. 62(7): 723730.

Turley, R. B., Vaughn, K. C and Scheffler, J. A., 2007, Lint De- velopment and Properties of Fifteen Fuzzless Seed Lines of Upland Cotton (Gossypium hirsutum L.). Euphytica, 156: 57-65.

Wilkins, T. A., Arpat A. B., 2005. The cotton fiber transcriptome. Physiol Plant., 124(3):295-300.

\section{How to cite this article:}

Sunil Kumar, G., N.V. Mohan Kumar and Katageri, I.S. 2017. Genetics of Fibre Elongation in Diploid Cotton. Int.J.Curr.Microbiol.App.Sci. 6(11): 453-457. doi: https://doi.org/10.20546/ijcmas.2017.611.053 